(i.e., Farmer, Moore, and Walker) " concluded that malignant new growths were virtually reproductive tissue arising in abnormal situations and possessed of an independence and power of growth like that of testis in the mammalian body." To our original prper ${ }^{1}$ we added a note emphasising that we did not accept this and other conclusions, as to the diagnostic value of the forms of cell-division in benign and malignant new growths, drawn by Farmer, Moore, and Walker.

I am, Sir, yours faithfully,

Jan. 13th, 1908.

E. F. BASHFORD.

\section{A NEEDLE 12 DAYS IN THE ALIMENTARY CANAL OF A CHILD 15 MONTHS OLD. \\ To the Elitor of THE LANCET.}

SIR,-The clinical note on the case of an open safety-pin in the cesophagus of a child published in THE LANCET of Jan. 4th makes me think that it might be of interest to mention a similar experience this last month in my own practice. A child 15 months old was playing with a needle one and a half inches long used for wool work and not having a very sharp point, when she put it in her mouth and swallowed it. I advised that a skiagram should be taken and the child watched for any untoward symptoms, and that the food should be as solid as possible. The parents did not take the advice as regards the skiagram, but anxiously watched the child from day to day. Nothing happened till the twelfth day when on the usual washing and straining of the fæces the needle was found.

Green-lanes, N., Jan. 8th, 1908.

$$
\text { I am, Sir, yours faithfully, }
$$
LEOPOLD G. HILL.

\section{THE COEFFICIENT OF DISINFECTANTS AS REGARDS THE PLAGUE BACILLUS. \\ Th the Editor of THE LANCET.}

Sir,-My friend Dr. J. O. Thresh in The LaNCET of Jan. 4th points out that bacillus pestis gives unsatisfactory coefficients when tested in broth cultures, and suggests that other bacteriologists may care to repeat his experiments and confirm or disprove his results. This is quite unnecessary, as Dr. Thresh's experience is not new but in accord with Simpson and Hewletit's work 2 who have shown that agar suspensions should be substituted for broth cultures when testing disinfectants with this organism.

I am, Sir, yours faithfully, SAMUEL RIDEAL.

Chemical Laboratory, Victoria-street, S.W., Jan. 9th, 1908.

\section{AMYL NITRITE IN HÆMOPTYSIS.}

To the Editor of THE LANCET.

SIR,-Dr. Reissmann has every right to traverse my views concerning the treatment of hæmoptysis by nitrite of amyl, but he has no right to assume that my note of warning in the matter was based upon mere theory. In point of fact the passage from my lecture which Dr. Reissmann quotes was inspired by two cases of hæmoptysis due to tubercle, in both of which the exhibition of the nitrite was immediately followed by death. I do not wish to lay too much stress upon these cases. One of the patients certainly, and the other possibly, would very shortly have died in any circumstances, but in each case the post hoc was sufficiently striking to suggest the propter hoc, and thus to point a warning against the indiscriminate and routine use of the drug, which appears, amongst residents at any rate, to be the fashion of the moment.

I am, Sir, yours faithfully

York-street, W., Jan. 11th, 1908. LEONARD WILLIAMS.

\section{THE MORPHINE HABIT AT THE AGE OF 87 YEARS.}

To the Editor of THE LANCET.

SIR,-A patient of mine, a lady, has just died from bronchitis at the age of 87 years and 11 months. She enjoyed to within a few days of her death absolute clearness of mind

Proceedings of the Royal Society, Jan. 21st, 1904. 2 The LanceT, August $20 \mathrm{th}, 1904$, p. 524 and acuteness of observation. Three years and a half ago she "broke her hip," with such subsequent pain that I was forced to administer hypodermically ${ }^{-2}$ th of a grain of morphine. No relief followed and the dose was raised through $\frac{1}{6}$ th, $\frac{1}{4}$, and $\frac{1}{2}$ grain to 1 grain twice daily. In spite of effort to the contrary on my part, larger doses followed, until for the past 18 months she has had (hypodermically) $2 \frac{3}{4}$ and sometimes 3 grains twice daily. The tolerance of the drug at this extreme age must be interesting. The usual distressing symptoms when waiting for the dose were present.

Jan. 11th, 1907. I am, Sir, yours faithfully,

\section{THE SPREAD OF CHOLERA: AN INFECTED HAJ.}

(From the British Delegate on the Constantinople Board OF HEAlTh.)

To those who have followed the recent course of the cholera epidemic in the Near East, as set forth in previous letters, it will not come as a surprise to learn that the pilgrimage to Mecca and Medina is already seriously infected with the disease. The pilgrimage culminates in the three days of Kurban Bairam, when the religious fêtes at Arafat and Mina, mear Mecca, take place ; those three days fall this year on Jan. 13th, 14th, and 15th. It is at that time, of course, that the number and density of the mass of pilgrims reach their highest point. But for several weeks before they accumulate, in constantly increasing numbers, both at Mecca and Medina, and the "roads," or rather the desert tracks between Medina and Yanbo on the one hand, between Jeddah and Mecca on the other, and finally those between Mecca and Medina, are being at the same time constantly traversed by unending streams of pilgrim caravans. Already both the holy cities of Islam, both the ports named, and two out of the three "roads" just mentioned are all seriously contaminated with the cholera infection.

It is not at present known how the infection was introduced to Mecca or to Medina. In Mecca a Soudanese woman was found to be ill with symptoms of cholera on Dec. 13th she was isolated and died on the next day. Microscopically bacilli resembling those of cholera were found in the intestinal contents. This woman was said to have come over from Suakim to Jeddah in a native boat, or "sambouk," at the beginning of the Moslem month of Ramazan (early in October) and to have reached Mecca at the end of that month. She is further said to have collected refuse of food left in the neighbourhood of a spot where some Indian pilgrims had camped in the Mesfelleh quarter of Mecca. This quarter is outside the walls of the town. On Dec. 17th another Soudanese, a male, fell ill and died. Then on the 18 th there were 4 fresh cases; on the 19th, 4 deaths and 2 cases isolated; and on the 20th, 3 deaths and 1 case isolated. Up to this date it was stated that all the cases had oocurred in the same quarter and exclusively among Soudanese. The later telegrams are silent on this point, but it may be surmised that the epidemic is no longer confined to one race or to one quarter of the town. The further course of the outbreak in Mecca has been as follows :-

\begin{tabular}{|c|c|c|c|c|}
\hline De & 21st & & $14 \mathrm{~d}$ & eaths \\
\hline , & 22nd & $\ldots$ & 17 & ", \\
\hline , & $23 r d$ & ... & 21 & , \\
\hline 29 & 24th & $\ldots$ & 18 & ", \\
\hline, & 25th & $\cdots$ & 13 & , \\
\hline 3 & $26 \mathrm{th}$ & 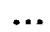 & 35 & ", \\
\hline , & 27th & $\cdots$ & 25 & . \\
\hline ", & 28th & .. & 25 & \\
\hline & $29 \mathrm{th}$ & $\ldots$ & 31 & , \\
\hline 3 & 30 th & $\ldots$ & 39 & 3 \\
\hline ", & 3Ist & $\ldots$ & 36 & 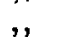 \\
\hline
\end{tabular}

$\begin{array}{lrc}\ldots & 1 & \text { case isolated. } \\ \ldots & 1 & ,, \\ \ldots & -1 & , \\ \ldots & 6 & , \\ \ldots & 8 & , \\ \ldots & 12 & , \\ \ldots & 15 & , \\ \ldots & 15 & , \\ \ldots & 16 & , \\ \ldots & 7 & , \\ \ldots & 15 & ,\end{array}$

By the last day of the year the total number of registered deaths from cholera in Mecca had risen to 283.

It is as yet uncertain whether Medina became infected by pilgrims from Mecca or by those coming from the north by way of Yanbo. The fact that cholera existed in Medina only became known by the arrival at Jeddah just before Christmas of a series of ships from Yanbo (the port for Medina) all seriously infected with the disease. But before describing these outbreaks mention should be made of a single case of cholera in the Abu-Saad lazaret close to Jeddah. As stated 